\title{
国際共同研究のためのネットワーク・コネクション \\ Cyber Connection for Cross-border Collaboration
}

\author{
岡伸人 ${ }^{\dagger}$, 岩田修一 ${ }^{\dagger}+$
}

Nobuto $\mathrm{OKA}^{\dagger}$, Shuichi $\mathrm{IWATA}^{\dagger \dagger}$

\begin{abstract}
複数の専門家がネットワーク上で協力して既往の知識を有機的に活用し問題解決 を促進するためのウェブ・プラットフォームを構築した。 ここで取り扱う情報は「コ ンテクスト (因果関係，経時変化)」「コンテンツ (専門知識に関するテキスト情報やデ ータベースに格納された数值データ)」「ノウハウ(計算機資源の活用法)」である。こ れらの情報を蓄積・再利用するために試作したシステムの機能の特徵は,「ネットワ 一ク上での情報の共有・活用」と「知的財産権への配慮」とのバランスへの配慮である. また材料分野の専門家を対象にしたこのシステムの試験運用の結果について，その 運用状況と中間評価についても報告した.
\end{abstract}

A web platform has been developed for experts to solve a given problem strategically by taking advantage of available information- data and/or knowledge. Information handled here are contexts (causal relation, consequence and time dependent properties), contents (textual information about specialized information and values in databases), and know-how (how to use computerized resources including simulation codes). It is the main concern of this prototype platform that a balance of sharing of information and appreciation of intellectual property right. This platform was used among materials experts in US and Japan through internet, and the results by such test users were reported.

キーワード：情報共有，コミュニケーション，共創, 知的財産権

Intelligence sharing, Communication, Co-creation, Intellectual Property Right

\section{1. はじめに}

現在，環境問題をはじめ多くの解決困難 な複雑現象が顕在化し，その解決を図るた め様々な取り組みが世界中でなされている.

\footnotetext{
†東京大学大学院工学系研究科

Graduate School of Engineering,

The University of Tokyo

nobuto. oka@gakushikai.jp

†東京大学大学院新領域創成科学研究科

Graduate School of Frontier Sciences,

The University of Tokyo

iwata@k.u-tokyo. ac.jp
}

これらの問題は, 環境・人工物・人間, それ ぞれの特性・活動が輻輳して多様に展開する 動的事象であるため, 旧来の手法や入手可 能なデータからだけでは解決が困難なもの となっている。このため, そうした複雑な 問題の解決に必要な決定を下寸場合, 不完 全な情報でも入手可能な情報を参照しつつ 再編し, 複数の関係者が当該問題の全体像 を俯瞰・共有し, 解決方策を模索しながら， 段階的に適切な解へと到達することになる. 問題解決の過程で得られる知識は関係者の 合意形成の中で適宜使われ，実践を通して 妥当性を確認し, 全体が少しずつ改良・進化 していくという性質を持っている ${ }^{[1]}$. したが って, 問題解決のためには, 問題自体につ 
いての「知識」やそれに対する「個々の人間の 理解や問題設定」を相互に共有し，関係者の 知的な相互作用を通して解決策を導出する （本稿ではこのプロセスを共創と定義する） というプロセス全体を包括的に支援する枠 組みが求められる.

本稿では, このように問題解決のために 様々な知識を持った人々が集まったネット ワーク的な組織をコミュニティと定義する. このコミュニティでは多数の属性の違う 人々から構成されるため, 平田らのいう専 門家間のインタラクションのダイナミック 性やコミュニティの構成のフラットさに大 きな特徵がある ${ }^{[2]}$. 一方，このコミュニティ の構成員が専門家集団である場合は，議論 の前提となる専門知識を共有しているため, コミュニティ一般を対象とする場合よりは, ネットワーク上での共同作業は容易である. そうはいっても，問題解決のためには，そ れに適した知識創造の「場」を用意する必要 がある。この「場」の応用としては，専門家 集団の国際共同研究のために利用寸ること を前提とした。時間的にも空間的にも交流 が非常に困難な物理的に離れた研究グルー プ同士が協力し，互いに自由に意見を交わ すことを考えた。

近年，ウェブ(World Wide Web)を通して, 多くの利用者が大量の情報を発信し, 社会 に存在するほとんどの情報がウェブ上に集 積されている。すなわち利用者にとってウ ェブは共通の情報インフラとなっていると いえるが，肝心の情報についての流通には 多種多様な知的財産権の主張が障害となる ことも少なくない，そこで本研究では利害 関係が少なからず存在する「国際共同研究に 関わる複数の専門家の知識を有機的に活用 し問題解決をはかるためのウェブ・プラット フォームを構築すること」を考えた。

現在, このシステムは, 東京大学大学院 新領域創成科学研究科環境学専攻の岩田修 一グループ (日本) とアイオワ州立大学の Krishna Rajan 教授グループ(U.S.A. ) との間 で，専門家向けのポータルサイトとして試 験運用されている。本稿では, その運用実 績も合わせて報告する.

\section{2. 関連システム}

様々な資源 (人・計算機・知識など)を共有 し，問題解決を試みるシステムとして，仮 想実験システム (VEML) ${ }^{[3] * 1}$, Information

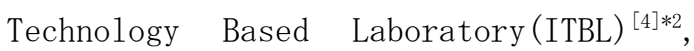
Social Networking Service(SNS) ${ }^{[5] * 3}$ などが 挙げられる.

しかし専門分野の問題解決の際には，VEML で試みられたように利用可能なデータやモ デルを駆使し，かつ ITBL で実現したより本 格的な計算環境を実現しなければならない。 より本質的な課題は, 問題の「特徵」を明確 に定義し，効果的に次善の策でも手がかり を得るための手順を策定することである. このためには，多くの場合，計算パラメー 夕の調整から補完的な情報の生成に至るま で，様々な試行錯誤が必要となる.

一方で，利用者に焦点を当てると，各々 の利用者 (専門家) は研究手法や背景知識な ど異なる特徵を持つため, そのままのデー 夕形式で彼ら/彼女らの情報を統合するだけ では有用ではないことが多く，目的に合わ せた情報の再編が必要である.

特に，情報の足りない部分を認知・補完し たり，ITBL や仮想実験システムのような既往 のアプローチで準備されたデータやシミュ レーション手法を活用したりしなければな らない。つまり最終的に問題解決に至るた めには，データとシミュレーション手法の 共有，プロセスの統合，そして様々なメ夕 データ, メタ知識の再利用ができるなど, 総合的な枠組みを持つ, システムが求めら れる.

*1 コンピュータを用いた物質・材料設計を実現するた めの, 数值シミュレーション, データベース, 知識情 報処理，可視化，ヒューマン・インターフェース等の物 質・材料設計のための要素技術を統合化したシステム ${ }^{[3]}$ *2 国内に散らばっている計算資源 (スーパーコンピュー タ, ソフトウェア, データベース等）を大容量ネットワ 一ク上に共有化し, 高度なシミュレーション等を行い, 地理的制約を受けない共同研究が可能な仮想研究環境 ${ }^{[4]}$ *3 趣味や嗜好, 交友関係, 仕事関係などをウェブ上で 電子的に接続し，参加者の共創作業による知識の蓄積 をサポートするシステム 


\section{3. システム実装}

\section{1. システムの概念設計}

本国際共同研究で構築した情報システム では，共有する情報は問題領域 (本稿では材 料分野) の専門家が自ら入力することを前提 とした.これはWikipediaが編集プロセスを 集中管理することをあきらめた代わりに， 情報提供と集積のスピードと幅を手に入れ たことと同様の考え方である.

そこで入力する情報を(1) コンテクスト (因果関係，経時変化)，(2) コンテンツ (専門 知識に関するテキスト情報やデータベース に格納された数值データ)，(3)ノウハウ(計 算機資源の活用法), に分類し，その分類に 応じてシステムの概念設計・開発をした．図 1 に概念図を記す。

まず(1)コンテクストに分類される情報の 入出力手続きについて述べる. 材料分野で 最も重要な情報である因果関係や経時変化 を的確に処理するため, 入力の際, プロダ クション・ルール (if A then B)による方向 性を持った表現(有向グラフ)を準備した. 問題解決を図る専門家にとって，過去の多 様な場面での情報を遡及的に参照すること を可能とするためである.

こうしたコンテクストの記述にあわせて， 時々刻々変化する知識を共有し, その中か
ら新たな問題解決を図る「利用者同士がコミ ユニケーションを行う場」を構築した。

次に (2) コンテンツに分類される情報の入 出力手続きについて述べる. コンテンツと して入手可能な情報源に，専門家の知見が 最も集約されている論文や教科書, 参考書 が挙げられる。これらの情報は限定的な専 門領域において，最も合理的な知識である といえる。しかしこれらの膨大な情報の中 から, 個々の問題の解決に適切な知識を抽 出する枠組みが必要となる. 本研究では, これらの情報をテキストデータベース（詳 細)およびそのビューア，そして無向グラフ によるリンクされた知識 (俯瞰図)のライブ ラリとして蓄積し, 提供することにした. さらに適用範囲の広い汎用の情報システム であるデータベースに収録されるデータも コンテンツとして利用できるように，関係 代数の操作と等価な論理演算が適用可能な アプリケーションポータル機能 ${ }^{[6]}$ 準用した. この機能の採用には開発者の知的財産権へ の配慮が含意されている.

最後に(3)ノウハウの代表例としては, 「誰かによって確立したと考えられている手 続き」に基づく計算機シミュレーションの使 い方を考えた。この情報も準備したアプリ ケーションポータル機能を通して，利用す ることができる.

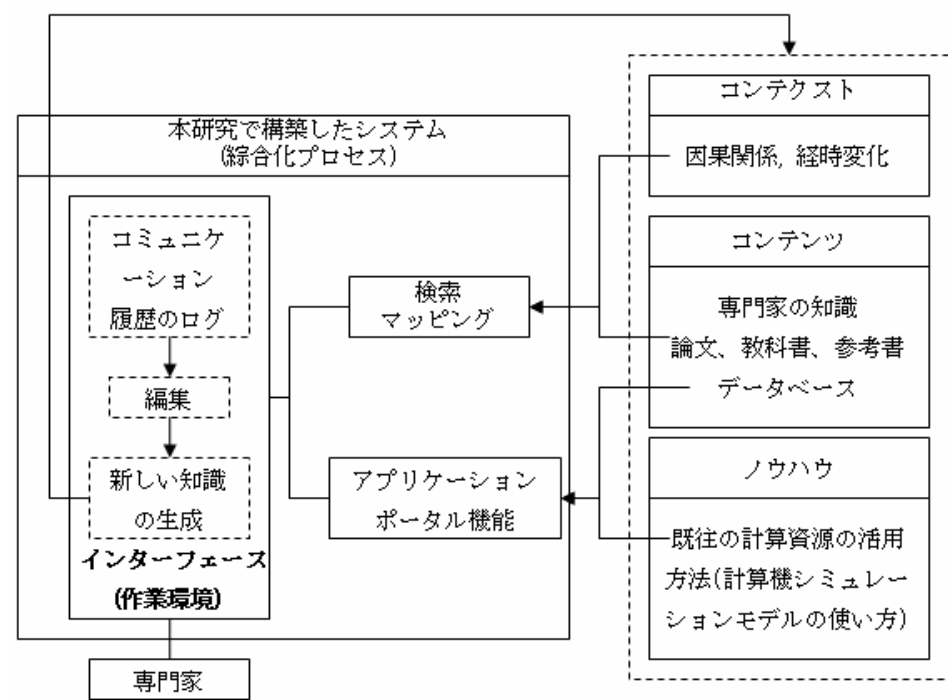

図 1. 構築したシステムにおける，情報の種類に応じたシステムの概念図 


\section{2. システムの説明}

Virtual laboratory と銘打った，今回構築 したシステムの主な機能について述べる(図 2).上述したように，利用者はウェブイン ターフェースを通してシステムを使用する。 システムは，「情報の蓄積・共有の場」,「利 用者同士がコミュニケーションを行う場」お よび「補助ツール」からなる。そして「情報の 蓄積・共有の場」は，知識・モデルを共有す るための場と, コンピュータプログラムを 共有するためのアプリケーションポータル 機能から構成される。また「補助ツール」と して，グラフ出力ツール・利用者情報 (名 前・連絡先・研究分野・研究協力者など)の 登録/表示機能・チャット・RSS フィードの配
信・メモ帳を備える.

3.2.1. 以降の節では，それぞれの機能に ついて詳細を述べる。

\subsection{1. 情報の蓄積・共有}

\section{・知識やモデルを蓄積・共有するための場} 本システムでは，「知識やモデルを蓄積・ 共有するための場」をWiki クローンの一つで ある PukiWiki ${ }^{\circ 2001-2005 \text { PukiWiki Developers Team. License is }}$ GPL. [7]を利用して構築した(図 3)。Wiki とは, ウェブブラウザから誰でもページを新規作 成したり，既存のページを編集したりする ことができるコンテンツ管理システムをさ す。これにより，利用者はウェブページ上 に自由に知識やモデルを記載し，参照し，

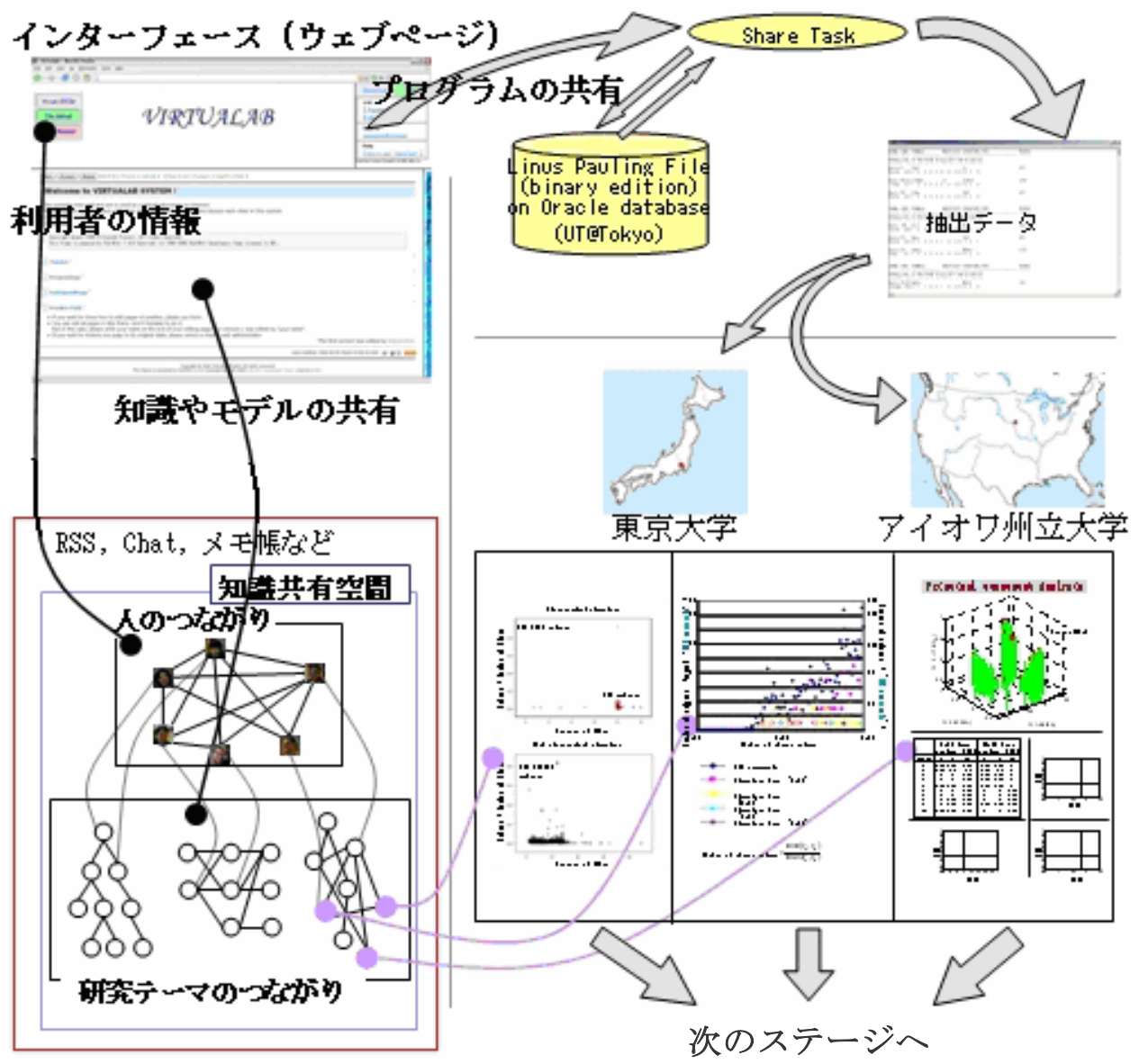

図 2. Virtual laboratory の主な機能 
議論することができる。この場には「研究テ 一マ」・「共有されたコンピュータプログラ ム・マニュアル」・利用者のページ」・「領域 知識ライブラリ」の 4 つのディレクトリを用 意した。

この「研究テーマ」ディレクトリ内には, 3.1. で述べたコンテクスト情報のみならず, 様々な形式のファイルをアップロードし蓄 積することができる。また広くコンテクス 卜情報をデジタル化するため，プロダクシ ヨン・ルール(if A then B)の A や B にあた る情報を「ユニット」，そしてユニット間を つなぐ関係性を「パス」と定義し，それらの 記述方法として自然言語を採用する。参加 者の知識はユニットおよびパス (ニニット間 をつなぐハイパーリンク)いう形でシステム に蓄積される. 図 3 にユニットとして蓄積さ れたページを示す。ページ最下部にはそれ を利用しているほかのユニットへのパスが 表示される.

また「共有されたコンピュータプログラ ム・マニュアル」ディレクトリ内には，アプ
リケーションポータルから利用可能なプロ グラムについての説明と使い方を蓄積する.

そして「領域知識ライブラリ」ディレクト リ内には，論文や教科書などから抽出した テキスト情報や共起頻度分析により構造化 された知識を蓄積する.

・アプリケーションポータル

今回，コンピュータプログラム本体を共 有するために, Share Task ${ }^{02005}$ ANCL, Inc. という コンピュータアプリケーションを使用した. 「Share Task」とは, PC クラスターやイントラ ネットあるいはインターネットに分散した 計算機のパワーを柔軟に統合することを目 的として設計された自律分散型ジョブ投入 システムである。このシステムは，利用者 からジョブの登録を受け付ける「ジョブ仲介 サーバ」と，ジョブ仲介サーバから自律的に ジョブを取り込み計算し結果を再びジョブ 仲介サーバに返す「計算サーバ」とから構成 される ${ }^{[6]}$.

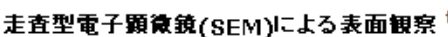

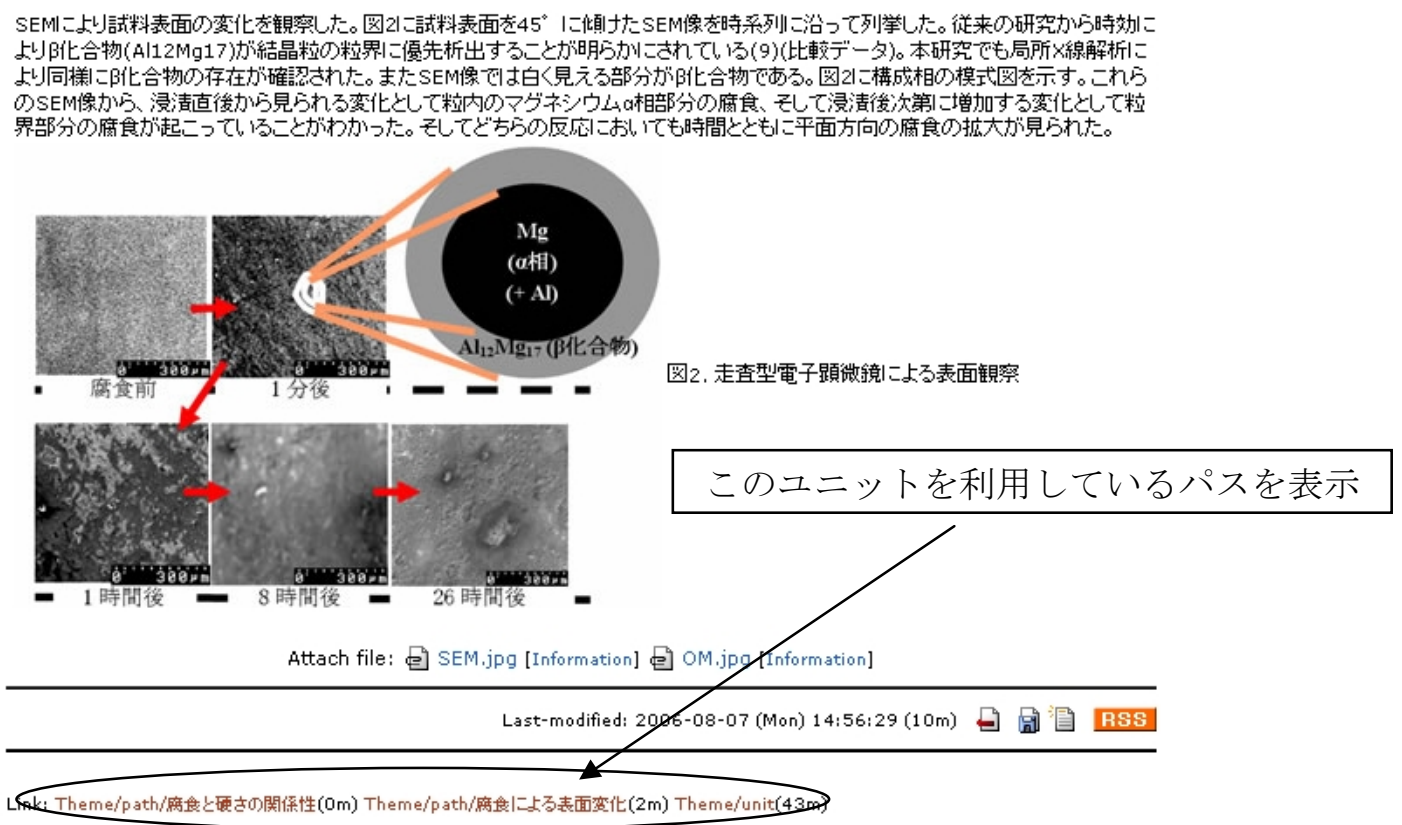

図 3. 知識やモデルを蓄積・共有する場

（蓄積された情報の例：生理食塩水環境下におけるマグネシウム合金の腐食表面変化） 
Virtual laboratory システムにおいてこの アプリケーションを利用した理由は，多く のコンピュータプログラムを共有してもら うためにも，その開発者の権利を守る必要 があると判断したためである。そのために システムが提供する「プログラムの共有機 能」を，「プログラムの共有」と「プログラム の機能のみ共有」の二つに分類した，前者の 場合は，プログラムを「知識やモデルを蓄 積・共有する場」にて共有し，利用者はそれ を自身のコンピュータにダウンロードして 使用することができる. 一方, 後者の場合, プログラムそのものは共有しない，プログ ラム開発者は自身のコンピュータを「計算サ 一バ」として登録することで，プログラムの 機能のみを Share Task を介して利用者に提 供することができる．また Share Task でプ ログラムを呼び出す際にプログラムの名称 を特定する必要があるため，その名称をあ る限られたグループにのみ公表することに すればその構成員だけにプログラムの機能 を提供することが可能となる.

現在，「計算サーバ」として登録されたも のは，統計用プログラム，および物質・材料 基礎データ Linus Pauling File (LPF) ${ }^{[8]}$ の中 の 2 元系化合物のデータの一部を収めたデー タベースである.

\subsection{2. コミュニケーションの場}

問題を解決するために，蓄積した情報を 検証したり利用者同士の知恵を持ち寄って 議論したりするための基盤システムとして 2 つのシステムを準備した.

ひとつはリアルタイムでコミュニケーシ ヨンをするための場として, A jax 技術を利用 したチャット機能をサーバ側に用意した. A jax とは非同期な XML 通信を応用した動的コ ンテンツの手法をさす.チャット機能をサ 一バ側に用意することで，チャットに参加 していなかった人もその議論の流れを追う
ことができる.

その一方で, 時系列に沿ったリアルタイ ム・コミュニケーションではなく, じっくり と多彩な議論をするためのコミュニケーシ ヨンの場として，3.2.1.の「知識やモデルを 蓄積・共有する場」を利用することにした. 理由は前述したとおり, システムの利用者 は誰でもページを作成・編集することができ るため, それぞれの参加者の注目する論題 についてしっかりと意見を交換できるから である.

また一方のコミュニケーションの場から もう一方のコミュニケーションの場をコン トロールすることが可能であるため, 情報 源となるページを相手に円滑に伝えること ができる.

\subsection{2. 補助ツール}

前述のように，本システムは「補助ツー ル」としてグラフ出カツール・利用者情報 (名 前・連絡先・研究分野・研究協力者など) の 登録/表示機能・チャット・RSS フィードの配 信・メモ帳を備える.

\section{・グラフ出カツール}

アプリケーションポータル経由で抽出し たXML データファイルの中から，ユーザにと って有意なデータを選択し利用するための グラフ出カツール(図 4)を構築した。 これは Java アプレットを用いて作成した。

\section{- 利用者情報の登録/表示機能}

この機能は, Perl プログラムにより構築さ れた利用者情報の登録・検索機能 $($ 名前・研 究分野・研究協力者・Email アドレス・Skype O2007 Skype Limited ${ }^{[9]}$ ID・ウェブページ・写真・ 所在地), および Google Maps API ${ }^{[10]}$ 利用し て構築された登録者情報一覧機能とからな る(図 5). 


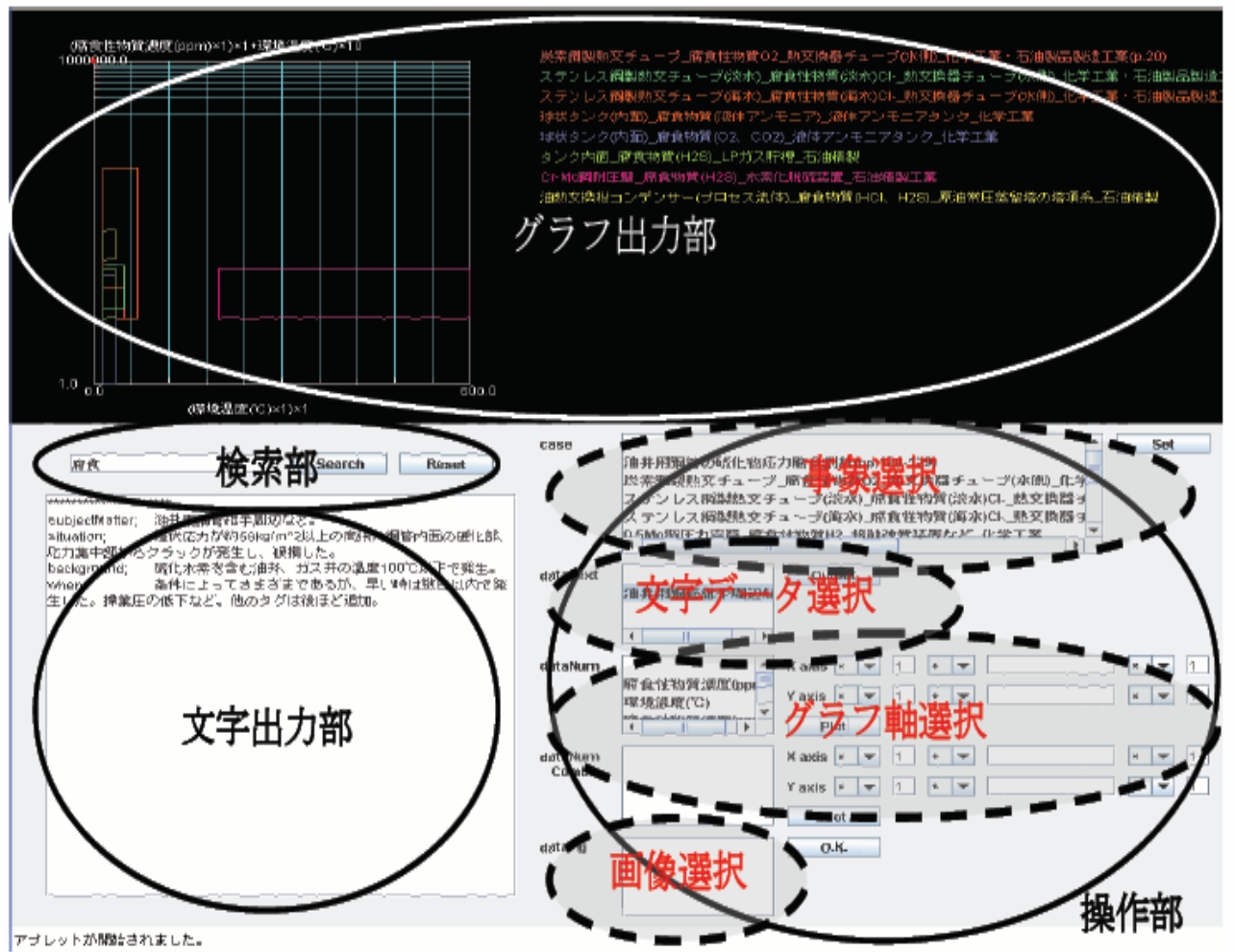

図 4. グラフ出力ツールの出力例

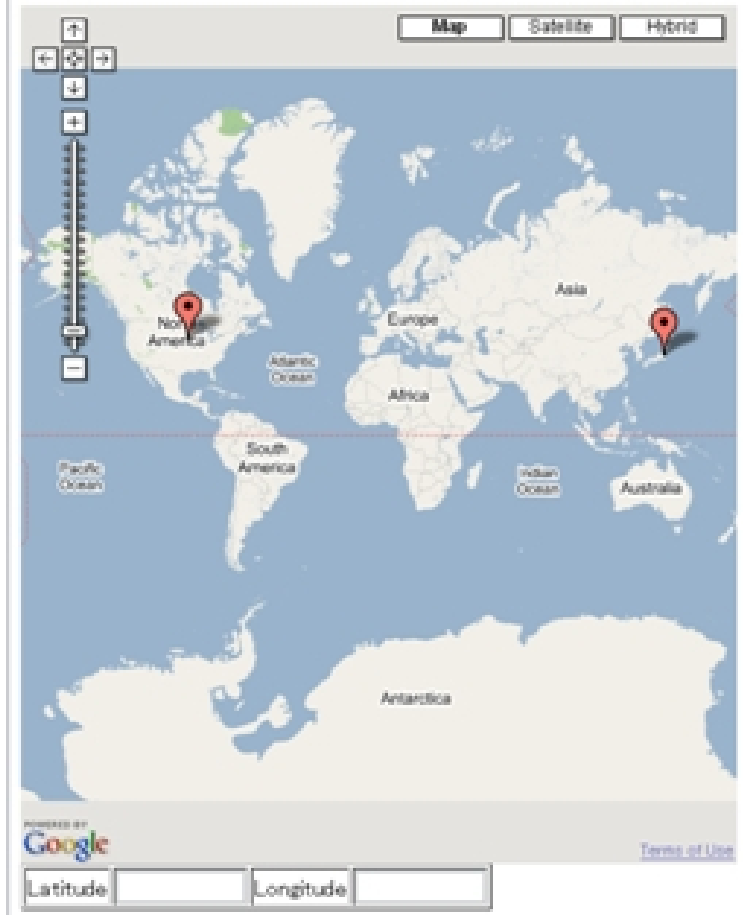

VL.AB Member

If the Skype status is 'I am not tefling", 2 meics "helahe is not there" of "he/she does not watt to display hisher Skype status" In the latter case, you can call himbler whth chicking the tikypebuesn. Back to top

Name: Nobues ORA

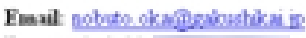

Research field:

Heman linkage:

Web page:

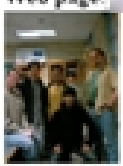

SkypeID; nimantins

e로

del

Back to top

図 5. 利用者の登録・検索機能 


\section{4. 運用実績}

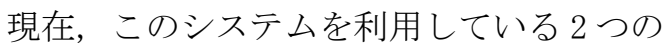
研究グループ (東京大学 岩田修一教授グル ープ(日本)・アイオワ州立大学 Krishna Rajan 教授グループ (米国))の特徵，および 各グループにおけるシステム利用者数を下 に示す.

\section{[岩田修一教授グループ］（利用者数：3）}

(http://ilab. q. t. u-tokyo. ac.jp/)

・物質・材料基礎データ LPF を用いた多元 系化合物の規則性抽出

- 第一原理的手法による材料設計

[Krishna Rajan 教授グループ]（利用者数:2) (http://mse. iastate. edu/krajan)

・統計分析手法を用いた物質・材料に関す る規則性の抽出

困 2 の右部には運用結果の一部を掲載して いる。これはアプリケーションポータルを 介して LPFから得られた出力データを，各々

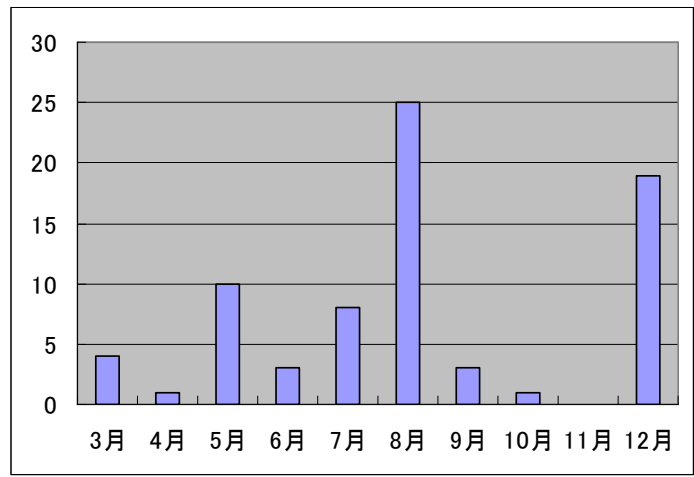

図 6. 蓄積された情報の更新回数

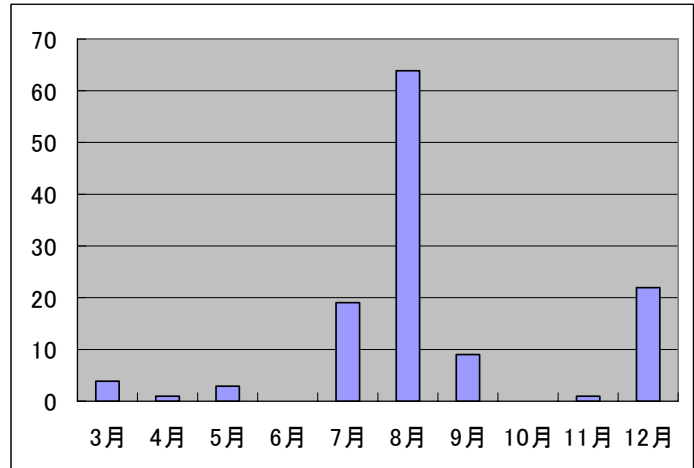

図 7. アプリケーションポータルを介した $\mathrm{LPF}$ データベースへのアクセス回数
のグループが解析した結果である。そして この結果を互いに「知識やモデルを蓄積・共 有する場」に記載し，ウェブ上もしくは Skype にて議論している.

次に試験運用期間 (2006 年 3-12 月)におけ る，蓄積された情報の更新回数(図 6)，およ びアプリケーションポータルを介した LPF デ ータベースへのアクセス回数 (図 7) を示す. 利用は互いの研究の進渉状況に依存するた め, 短期的には利用頻度は大きく変動して いるものの，長期的には安定した利用が期 待できる結果を得ることができた.

またシステム利用者からの意見を下に記 す.利点として,

・多様な機能をシームレスに利用でき，状 況に応じた利用ができた

・従来の掲示板などのシステムとは異なり, 誰でも知識を系統付けて整理することが できるため，論点を明確に議論すること ができた

欠点として,

・ 入力インターフェースが直感的ではない などの意見が寄せられた。このように操作 性の面で慎重な意見もあったが，システム の有用性に対して概ね肯定的な意見となっ た.

\section{5. 考察}

今回構築したシステムでは，コミュニケ ーションの場やアプリケーションポータル 機能などをひとつのインターフェース上で 連携させて利用することができるため， 様々な試行錯誤を伴う知識の生成および検 証を行うための作業環境となっていた。し かしこのプラットフォームの外にある巨大 な情報システムとの相互運用可能性につい ては未検討で, 今後の課題である。これか らの情報コモンズ関係の世界的動向 (たとえ ば Committee on Data for Science and Technology (CODATA) ${ }^{[11]}$ )に着目しながら，相 互運用可能性について考える必要がある. 


\section{6. 結論}

国際共同研究に関わる複数の専門家の知 識を活用し問題解決をはかるために，次の 機能を持つウェブ・プラットフォームを構築 した.

- 因果関係，経時変化といったコンテクス 卜を蓄積・共有する場

- 開発者の権利を守り，管理コストを低減 し，シミュレーションソフトウェアの有効 利用を促進するためのアプリケーションポ ータル

- 専門家間のコミュニケーションの場

- グラフ出力機能などの補助ツール

本システムを日米間の 2 グループで運用し た結果，それぞれの知的財産権を保護しな がら，利用可能なデータ，知識をゆるやか に統合し，それらの情報を効果的に専門家 に提供する快適な作業環境となっているこ とを確認した.

このシステムは，本格的な問題解決型情 報システムへと段階的に成長させるための 基盤となると考えている.

\section{謝辞}

本研究の実施にあたって，アイオワ州立 大学の Krishna Rajan 教授, Changwon Suh 博 士に様々な助言を頂いた。ここで，深い感 謝の念を表しておきたい.

\section{参考文献}

[1] 井田淳, 梅本勝博：「NP0 のナレッジ・マ ネジメント」, ノンプロフィットレビュー, Vol. 3, No. 1, pp. 37-45, 2003.

[2] 平田高志，村上晴美，西田豊明：「連想
表現と分身エージェントを用いたコミュニ ティにおける知識共有支援」, 人工知能学会 論文誌， 16 巻 2 号 I, pp. 225-233， 2001.

[3] 小池秀耀，西川宜孝：「物質・材料設計 のための仮想実験システム」，第 4 回物質・ 材料設計のための仮想実験技術シンポジウ ム, pp. 78-91, 1999.

[4] ITBL project: http://www-riken. riken. $j p /(2006$ 年 8 月 1 日 参照)

[5] Misja N. Hoebe, Rien Bosma: $\lceil\quad$ Visualizing multiple network perspectives 」, Proceedings of the conference on Dutch directions in HCI, 2004.

[6]（株）情報数理研究所：「Share Task」, http://www. imslab. co. jp/products/pro_to p. html（2006 年 4 月 20 日参照).

[7] PukiWiki Developers Team:「PukiWiki」, http://pukiwiki. sourceforge.jp/ (2006 年 4 月 20 日参照).

[8] S. Iwata, X. Ge, Y. Kotlyarov, Y. M. Mi, P. Villars, H. Odaka, Y. Chen, Y. Kaneta, et al. : 「Materials Design by Taking Advantage of Linus Pauling File Environments $\rfloor$, International Symposium on User Aspects of Phase Diagrams, Sendai, Japan Sep. 2000.

[9] Skype Limited: 「Skype」, http://www. skype. com/ (2006 年 4 月 20 日参照).

[10] Google:「Google Maps API 」, http://www. google. com/apis/maps/ (2006 年 4 月 20 日参照),

[11] Committee on Data for Science and Technology, http://www. codata. org/ (2007 年 2 月 10 日参照).

(2006 年 5 月 12 日受付)

(2007 年 2 月 16 日採択) 